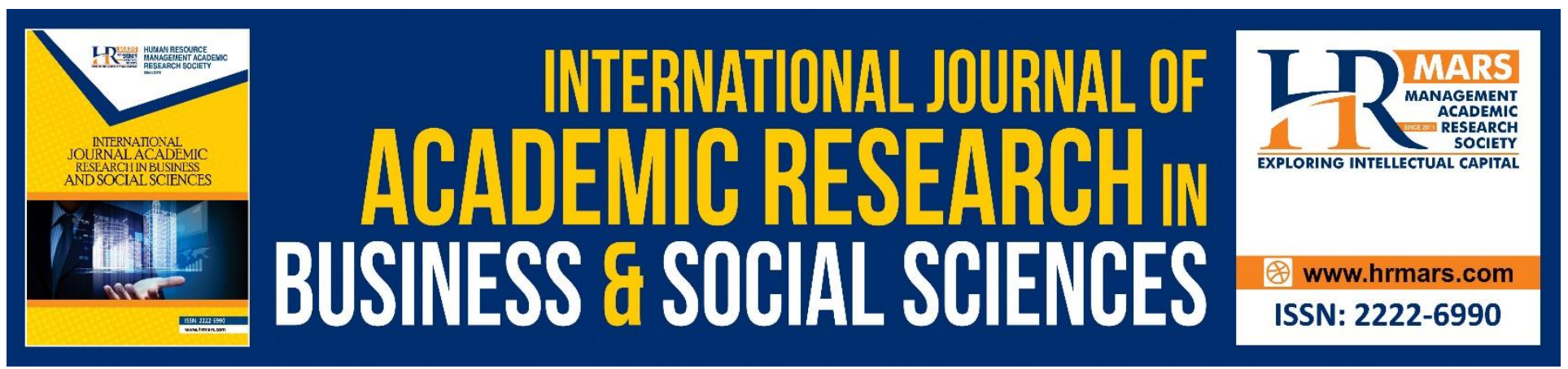

\title{
Effects of Microfinancing on Performance of Entrepreneurship: A Study of Selected Counties in Western Kenya
}

Martin W.O. Madara, Maria Adhiambo Onyango, Michael Otieno Nyagol

To Link this Article: http://dx.doi.org/10.6007/IJARBSS/v10-i7/7417

DOI:10.6007/IJARBSS/v10-i7/7417

Received: 02 April 2020, Revised: 06 May 2020, Accepted: 16 June 2020

Published Online: 24 July 2020

In-Text Citation: (Madara et al., 2020)

To Cite this Article: Madara, M. W. O., Onyango, M. A., \& Nyagol, M. O. (2020). Effects of Microfinancing on Performance of Entrepreneurship: A Study of Selected Counties in Western Kenya. International Journal of Academic Research in Business and Social Sciences, 10(7), 296-319.

Copyright: @ 2020 The Author(s)

Published by Human Resource Management Academic Research Society (www.hrmars.com)

This article is published under the Creative Commons Attribution (CC BY 4.0) license. Anyone may reproduce, distribute, translate and create derivative works of this article (for both commercial and non-commercial purposes), subject to full attribution to the original publication and authors. The full terms of this license may be seen

at: http://creativecommons.org/licences/by/4.0/legalcode

Vol. 10, No. 7, 2020, Pg. 296 - 319

http://hrmars.com/index.php/pages/detail/IJARBSS

JOURNAL HOMEPAGE

Full Terms \& Conditions of access and use can be found at http://hrmars.com/index.php/pages/detail/publication-ethics 


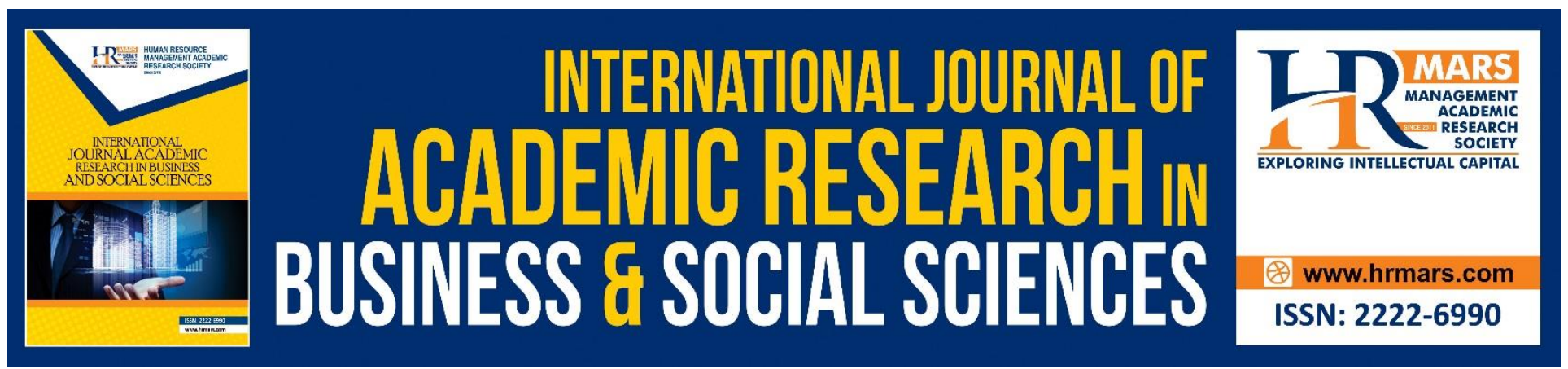

\title{
Effects of Microfinancing on Performance of Entrepreneurship: A Study of Selected Counties in Western Kenya
}

\author{
Martin W.O. Madara, Prof. Maria Adhiambo Onyango, Dr. Michael \\ Otieno Nyagol
}

School of Business \& Economics, Jaramogi Oginga Odinga University of Science and Technology, Bondo, Kenya, P.O. Box 122-40100, Kisumu-Kenya.

Email: momadara@gmail.com

\begin{abstract}
Micro and Small Enterprises (MSEs) play a key role in economic development of the informal sector of many nations. Vast literature on MSEs growth cites financial challenges for startups and working capital. To address this gap, Many Microfinance Institutions have targeted Micro-Entrepreneurs with credit, savings products however; limited studies have addressed the extent in which such initiatives have stimulated the entrepreneurial spirit of individuals targeted. Kisumu, Siaya and Vihiga counties of Western Kenya which were targeted in this study lie in the same economic belt and share similar business culture. The Micro Financing Services explored in the study included Microcredit and Savings Mobilization. The study targeted 65,698 MSEs out of which a sample of 398 was selected. The study purposed to examine the effects of Micro financing services on the performance of MSEs. The study employed descriptive survey design and used structured questionnaires to collect primary data. Data was analyzed using statistical software (SPSS) and presented in descriptive and inferential statistics. The study found that access to microcredit and savings mobilization as independent variables significantly explains the variance in MSE Performance. The study conclusion is that micro-financing contribute to MSEs growth and expansion. The study recommends Public-Private-Partnership whereby Government provides guarantee funds to financial institutions who advance loans to MSEs, as well Government to provide tax incentives to financial institutions that specializes in financing the MSEs sector in Kenya. An in-depth study could be conducted to find out if, financing of MSEs contribute to increase in employment.
\end{abstract}

Keywords: Microfinance, Micro and Small Enterprises, Micro-entrepreneurs, Entrepreneurship.

Introduction

According to Micro and Small Enterprises Act 2012 Laws of Kenya (MSE Act, 2012), Micro Enterprises have annual turnover of less than Ksh .5m, and employ up to ten employees, while Small Enterprises 
INTERNATIONAL JOURNAL OF ACADEMIC RESEARCH IN BUSINESS AND SOCIAL SCIENCES Vol. 10, No. 7, July, 2020, E-ISSN: 2222-6990 @ 2020 HRMARS

are those with Annual Turnover of between Ksh $0.5 \mathrm{~m}$ and $\mathrm{Ksh} 5 \mathrm{~m}$ and employs between ten to fifty employees (MSE Act, 2012). Micro and Small Enterprises (MSE) play a major role in economic development (Pietro, Chando, \& Sofiane, 2012). MSEs contribute on average 60 percent of total formal employment in the manufacturing sector (Ayyagari \& Demirgüç-Kunt, 2007). In Kenya the MSEs is recognized for its role in provision of goods and services, enhancing competition, fostering innovation, generating employment and in effect, alleviation of poverty.

The role of MSEs is underscored in Kenya's Vision 2030 - the Development Blueprint for transforming Kenya into an industrialized middle-income country, providing a high-quality life to all its citizens by the year 2030. GOK, (2017), reiterate that Kenya Government has identified and prioritized MSEs sector as a key growth driver for achievement of the development blue print. A crucial element in the development of the MSE sector is access to finance, particularly to bank financing, given the relative importance of the banking sector in serving this segment. Firm-level data collected by the World Bank show that access to finance is perceived as one of the main obstacles to doing business (World Bank, 2014). It is, therefore, unsurprising that the international development community has listed MSEs access to finance as an important policy priority. This is compounded by the fact that comprehensive data on MSEs finance is still to be more consistently collected and monitored over time (Pietro et al., 2012).

The Kenya Government has successively been developing and implementing various plans and strategies to address not only the rapidly widening unemployment but as well the increasing poverty (GOK, 2008).The GDP growth of Kenya has been low and limited to only a few sectors tourism, manufacturing, horticulture, and services. The government needed to radically improve the nation's investment and savings habits which drastically threaten growth, since substantial growth cannot occur without sufficient capital (GOK, 2003). Encouraging the systemized implementation of savings and capital accumulation strategies the Government felt it could allow Kenya to swiftly grow GDP at rates that far exceed the current pace (KNBS, 2015). At the grassroots level, microfinance and microenterprise growth was felt to be playing a critical role in bringing capital, financial strategies, and economic opportunity to underserved communities throughout Kenya (KNBS, 2003).

The Kenya Government committed itself to maintaining a stable macroeconomic framework, reforming the financial sector and strengthening its regulations to increase savings and investment, implementing mechanisms for private sector participation in provision of infrastructural services, and establishing a competitive environment, able to attract increased private investment in productive sectors such as tourism, industry and trade (GOK, 2003).An in-depth analysis of private investment behavior in Kenya indicates that private Investment is driven by: growth in national income; profitability; interest costs; crowding-in factor of public investments; and availability of credit to the private sector. The main objective of financial sector reforms was to enhance the environment for private savings and investment, and lower interest rate levels and spreads (GOK, 2003).

World Bank, (2016), on Kenya Economic Updates, firm creation is a pathway to productivity, growth and employment creation. Young firms contribute disproportionately to job creation and much less to job destruction. However, creation of new firms and formalization of existing firms in Kenya is sluggish, curtailing growth prospects. For instance, young firms account for 35 percent of all firms in the US and 30 percent in OECD countries compared to only 10 percent in Kenya. 
The importance of the sector was also affirmed in the African Economic Outlook, 2011 report. According to the report, the MSEs subsector plays a significant role in the Kenya's economic structure, where the sector employed close to $80 \%$ of Kenya's total workforce in 2011 (AfDB, OECD, UNDP, \& UNECA, 2011). The value of the MSEs output is estimated at KSh 3,371.7 billion against a national output of KSh 9,971.4 billion representing a contribution of 33.8 per cent in 2015. In terms of gross value-added, the MSEs are estimated to have contributed KSh 1,780.0 billion compared to KSh5, 668.2 billion for the whole economy (KNBS, 2012).

\section{Problem Statement}

Micro and Small Enterprises are seen as risky ventures by formal financial and banking institutions. They have limited financial track performance and shrouded with uncertainty in market trends. Formal financial and banking institutions hesitate to advance credit to them due to high transaction costs as the loans are small, have low returns to the financing institutions and their unpredictability and survival especially in the early stages (Oppong, 2015). While entrepreneurship might not necessarily be tied to finance, availability of financial resources could promote entrepreneurship development. MSEs require finance for expansion, productivity and growth yet the majority selffinances their operations. Analysis of the World Bank Enterprise survey data 2013 suggests that close to $68 \%$ of Kenyan Enterprises; accept that access to finance is a challenge. According to the survey, $50 \%$ of the Kenyan MSEs have never approached a bank and only $36 \%$ of Kenyan MSEs have accessed loans as compared to OECD average of 51\%. In spite of the perceived importance of the contribution of entrepreneurship and MSEs growth, limited research has explored on role of financing on their promotion and how banks finance MSEs around the world. This is compounded by the fact that comprehensive data on MSEs finance is still to be more consistently collected and monitored over time (Pietro et al., 2012). It is known that banking system finance big enterprises and tend to be more conservative toward MSEs (Shahini, 2016). In the wake of the devolved Kenya government system, wide ranges of special micro-financial institution have sprung up to address surplus labor and reduce poverty. This research therefore assessed the effects of micro financial services on entrepreneurship performance in selected counties in western Kenya.

\section{Objectives of the Study}

1) To assess the effects of microcredit on the growth and expansion of MSEs in Kenya

2) To establish the effects of savings on the performance of MSEs in Kenya

\section{Literature Review}

\section{Theoretical Framework}

The study was anchored on Shane's General theory of Entrepreneurship, and Muhammad Yunus Classic Microfinance theory of Change.

\section{Shane, a General Theory of Entrepreneurship}

Shane (2003) posits that entrepreneurship consists of opportunity discovery, evaluation of the opportunity and the decision to exploit the opportunity to introduce new goods and services, ways of organizing markets, processes, and raw materials through organizing efforts that previously had not existed. According to Shane's theory, the success of an entrepreneurial venture is dependent on 
the capability of the owner of MSE to tap the opportunity. Sarasvathy (2014), also argue that even when the opportunity exists in an ontologically objective manner, the particular beliefs and circumstances of each potential entrepreneur make the decision facing them fundamentally different. The decision of the owner of MSE for exploiting the market opportunity calls for financial resources that are through credit and savings.

Shane's work took a provocative side positions; Shane believed that entrepreneurial opportunities exist independent of the actors in a system. In support of Shane theory, Haider, Asad, Fatima \& Atiq, (2017), observed that every price, every invention, every bit of information already engenders within itself opportunities for the creation of new ends. Klein (2008) however stated that human creativity have to exist for the objective opportunity to be brought to life. Opportunities themselves lack agency until complemented through human agency for discovering entrepreneurial opportunities because discovery is a cognition process which hinges its meaning on the entrepreneur. This is relevant to this study in that for an opportunity to be exploited for creation of a new venture there has to be an agency of a dynamic human being.

\section{The Classic Microfinance Theory of Change}

The classic microfinance theory of change was advocated by Yunus, (1999) when he founded the Grameen bank later after lending money to the poor since 1976. According to Dunford (2012), a poor person goes to a microfinance provider and takes a loan (or saves the same amount) to start or expand a microenterprise which yields enough net revenue to repay the loan with major interest and still have sufficient profit to increase personal or household income enough to raise the person's standard of living. The World Bank's 2008 Poverty Assessment indicate that, Microfinance provide change, even without the income gains, the poor may still benefit from microcredit services if it helps them withstand income and non-income shocks such as an economic disaster resulting from the sudden death of a productive family member, the loss of an economic asset, or natural disasters. Several studies confirm that micro-credit programmes help households partially insure against shocks so that they effectively play an important "safety net" role. A few studies show that microcredit does little to change gender inequities by limiting female control over loans (Khandker \& Zaman, 2011).

Bateman (2019) criticized Yunus theory of change that it was based on a famous fallacy known to economists as Say's Law - the idea that supply creates its own demand. Yunus misunderstood the nature of markets, competition, demand constraints and the crucially important zero-sum aspects to local development interventions under ultra-competitive capitalism in the Global South. By wrongly assuming that increasing the local supply of simple goods and services typically used by the poor would always find or create the local demand (purchasing power) required to fully absorb this increased supply. Even though the classic microfinance theory of change is criticized, it still remains one of the pillar theories in study of Microfinance, therefore, stands as the most significant theory to underlie this study. This is because the theory supports the low income earners to access microfinance for startups and for expanding their enterprises which is in line with the study objective.

\section{Global Entrepreneurship Concepts}

The concept of "entrepreneur" and "entrepreneurship" have gone through various stages before they came to signify the content being put into them now (Latha, Madhavaiah, \& Murthy, 2008). The 
INTERNATIONAL JOURNAL OF ACADEMIC RESEARCH IN BUSINESS AND SOCIAL SCIENCES Vol. 10, No. 7, July, 2020, E-ISSN: 2222-6990 @ 2020 HRMARS

concept of entrepreneur has transitioned from economic field of creating any enterprise to an adjective defining an undertaker who takes all risks to find a viable venture. Economists have recognized the entrepreneur as essential agent in generating investment opportunities. Sociologists analyze him as sensitive energizer in modernization of societies. Psychologically an entrepreneurial man has motivations and aspirations consistent with discerning favorable conditions for economic development. Political scientists see entrepreneurship as the fair child of political system who provides effective assistance for his emergence, (Shravanvel, 1987).

Since the turn of the century, there has been increased global interest in entrepreneurship both by individual theorists and by institutions. This is significant because over the last quarter of a century there has been a remarkable renaissance in terms of the recognition of small firms (McFarlane, 2016). Cantillon, (1755) was the first economist to acknowledge the entrepreneur as a key economic factor in his post humors he introduced the concept of entrepreneurs (Hisrich, Peters \& Shepherd, 2009).The earlier period development of the theory of entrepreneurship parallels to a great extent the development of the term entrepreneurship. The word entrepreneur is French and literally, was translated to mean "between-taker" or "go-between" (Saleemi, 2011).

\section{The Kenyan Informal Sector and Entrepreneurship Trend}

The International Labour Organization's (ILO) pioneering work on informality began in Africa with the Kenyan multidisciplinary employment mission in 1972. In Africa, the majority of the labor force is in the informal economy. It is estimated that as many as nine in ten rural and urban workers have informal jobs (ILO, 2009). In Kenya the informal sector account for higher percentage of not only job creation but reducing poverty as the majority of players are the low income and rural based enterprises (Koech, 2011). The importance of Entrepreneurship in Kenya was first recognized in the ILO report, in 1972 on „Employment, Income and Equity in Kenya“ (ILO, 1972). The sector's importance in economic development was singled out in Sessional Paper No.1 of 1986, Economic Management for Renewed Growth (GOK, 1986), which set out mechanisms for enhancing an enabling environment for MSEs. The Government's commitment in Sessional Paper 1 of 1986 was reinforced in the 1989 GOK report, the strategy for small Enterprises, which delineated the mechanisms for removing the constraints to growth and the development of the MSE sector (Ong'olo \& Awino, 2013).

ILO (2009), contend that, while some activities in the informal economy offer reasonable livelihoods and incomes, most people engaged in informal activities face a wide range of decent work deficits and often remain trapped in poverty and low productivity. Emphasis on Kenya owned enterprises has been established since independence including Sessional Paper No. 10 of 1965 on African Socialism and its Application to Planning in Kenya. Starting with Development plan of 1974-1978, a number of Development Plans introduced policy prescriptions aimed at addressing the sector (GOK, 1989). This was followed by the 1986 Sessional Paper No. 1 on Economic Management for Renewed Growth and other sessional papers that followed after that. The Kenya Government also developed strategy papers to address specifically MSEs, like the Private Sector Development Strategy (PSDS) which avers that MSEs are a crucial link between the private sector and poverty reduction. The Kenya Vision 2030 underscored the MSEs as growth drivers for Kenya to be transformed into "middle income country providing quality life to all its citizens by the year 2030" (KNBS, 2016). 
INTERNATIONAL JOURNAL OF ACADEMIC RESEARCH IN BUSINESS AND SOCIAL SCIENCES Vol. 10, No. 7, July, 2020, E-ISSN: 2222-6990 @ 2020 HRMARS

\section{Entrepreneurship and Economic Development}

Entrepreneurship has developed in a systematic way since the beginning of Industrial Revolution in Europe. The development of entrepreneurship is essential for rapid economic growth and has engaged the attention of economists, sociologists, and psychologists to study the phenomenon in the developed and developing countries in recent years (Latha et al., 2008). Saleemi (2011) observed that Joseph Schumpeter argued that the rate of growth in an economy depends to a great extent on the activities of the entrepreneur and has probably put greater emphasis on entrepreneurial functions than any other economist. Micro and Small Enterprises play a key role in economic growth and industrial development of a country (UNIDO, 2012). Thus they make vital contributions in improving economic and social sectors of a country through stimulating large scale employment, investment, development of indigenous skills and technology, promoting entrepreneurship and innovativeness, enhancing exports, and also building an industrial base at different scales.

Saleemi (2011) summarizes the development contribution of entrepreneurship as "developing new markets, discovering new sources of raw materials, mobilization of capital resources, introducing new technologies, new products, new industries and creating employment". According to the Kenya Economic Survey (2003), employment within the MSE sector in Kenya increased from 4.2 million persons in 2000 to 5.1 million persons in 2002, accounting for $74.2 \%$ of the total persons engaged in employment (KNBS, 2003). The sector contributes up to $18.4 \%$ of the country's Gross Domestic Product (GDP). The MSE sector is therefore, not only a provider of goods and services, but also a driver in promoting competition and innovation; and enhancing the enterprise culture which is necessary for private sector development and industrialization (GOK, 2005).

\section{Growth of Micro and Small Enterprises (MSEs)}

MSEs growth has been quite elusive, and therefore most discussions on MSEs growth have been in some instance taken to mean the wellbeing of the Entrepreneur. According to Muiruri (2014), the growth of Kenya Micro and Small Enterprises (MSEs) into Small business enterprises (SMEs) into big companies, with a turnover of one billion, is as low, if not a disheartening statistics. He qualified it further by asserting that out of top 100 MSEs surveyed by the Business Daily, and KPMG in 2008 only four companies graduated from SMEs class in survey of 2009 to one billion mark, representing only four percent.

There are a number of theories that have been advanced on the growth of the MSEs as it is, there is no single theory which can adequately explain small business growth (Smallbone, Leigh \& North, 1993). This is partly because of the heterogeneity that exists in the various types of MSEs but also because of the range of factors that can affect growth, which may interact with each other in different ways in different circumstances (Smallbone et al., 1993). Berger \& Udell (1998), proposed a financial growth cycle for small business where small businesses at different business cycles apply different forms of financing. They contend that changes in optimal capital structure are a function of the firm size, age, and information availability. In addition to firm characteristics, the demographic origins of small business owners may also affect financing decisions and growth. Most of the rural based MSEs are agro based and therefore many financial institutions including Microfinance are hesitant to transact with them due to risk related to agricultural production so are likely to miss financial capital for growth (Madara, 2005). 
Studies that have been undertaken on MSEs growth have majorly been based on the law of Proportionate Effects or Gibrat's law (Bouazza, Ardjouman \& Abada, 2015). Gibrat's law states that firm growth rate is independent of firm size (Gibrat, 1931). While some studies agree with Gibrats'law others do not (Hart \& Prais, 1956). In her book, The Theory of the Growth of the Firm, Edith Penrose (1959), offered some strong principles governing the growth of firms and the rate at which firms can grow successfully (Nair, Trendowsk \& Judge, 2008). For firms to grow they need both the internal and external resources which will enable them to face competition as well. Nair et al., (2008), reports that according to Penrose, firm size is incidental to the growth process, whereas firm growth is determined by the effective and innovative managerial resources within the firm. She further explained that the availability of top managerial and technical talent serves as an engine to a firm's growth.

\section{Kenya Government and MSEs}

A poor business environment can disproportionately affect micro and small enterprises (MSEs) (White, 2018). A World Bank Report on Doing Business advocates for both regulatory, quality and efficiency. It is important to have effective rules in place that are easy to follow and understand. To realize economic gains, reduce corruption and encourage MSEs to flourish, unnecessary red tape should be eliminated (World Bank, 2019). Micro and Small Enterprises cut across all sectors of the country's economy and provide one of the most prolific sources of employment, not to mention the breeding ground for medium and large industries, which are critical for industrialization. Today, these enterprises are found in every corner of Kenya and they have great potential for creating a variety of jobs, while generating widespread economic benefits (GOK, 2005). KNBS, (2012) Economic Survey, shows that it was more difficult for MSEs to access loans from commercial banks than from other small financial institutions. To solve the problems faced by MSEs the business owners expressed their wish for the Government to assist in market promotion and to provide an enabling environment for fair competition.

KNBS, (2016) Economic Survey, report that over the years, traditional sources of financing for MSEs have revolved around personal savings, loans from friends and family, and other informal sources. To encourage greater bank-led financing, the Central Bank of Kenya (CBK) increased its focus on the MSE sector through several lending and credit facilitation programs. This is mainly to bridge the unmet funding demand and to maintain the flow of banking credit (KNBS, 2016). Total amount of loans applied for by licensed MSEs in the last three years was Ksh 707.3 billion, out of which Ksh 644.1 billion was given, translating to 91.1 per cent. Total amount received by unlicensed MSEs was 42.9 billion representing 92.3 per cent of loans applied (KNBS, 2016).

\section{Evolvement of Microfinance and its Impact}

Although lending to low income groups is as old as beyond 15th century when the practical visionaries Franciscan monks founded the community-oriented pawnshops, and 19th Century when the European credit movement were founded, Microfinance has been traced to the time when Professor Muhammad Yunus started the Microcredit movement in 1970s in a village in Bangladesh which was later known as Grameen Bank, a model that was replicated by many practitioners in many developing countries (Egboro, 2015). Microfinance can be loosely defined as the provision of small loans to those who would not typically be able to borrow due to a lack of collateral (Shepard, 2015). According to 
INTERNATIONAL JOURNAL OF ACADEMIC RESEARCH IN BUSINESS AND SOCIAL SCIENCES Vol. 10, No. 7, July, 2020, E-ISSN: 2222-6990 @ 2020 HRMARS

the World Bank (2014), microfinance is widely considered to have emerged as a response to the failure of the formal financial sector to serve the needs of rural populations, informal sector workers and people living in poverty. Microfinance movement aims at "a world in which as many poor and near-poor households as possible have permanent access to an appropriate range of high quality financial services, including not just credit but also savings, insurance, as well as trainings (UN, 2013).

According to the Microcredit Summit Campaign, microfinance institutions had $154,825,825$ clients, more than 100 million of them women, as of December 2007 (Banerjee, Dufflo, Glennerster \& Kinnan, 2009).Since then studies have been conducted to trace the impact of microfinance as a poverty reductions tool and there has been mixed results from different reports with some confirming that the accessibility of microfinance services has assisted the poor in achieving the millennium development goals thus serving as a tool for poverty reduction, while others critique the evidences available, that microfinance creates positive impact on the lives of the poor and feel that microfinance is working in preventing the implementation of anti-poverty and even leading to over borrowing by the poor thus deepening poverty (UN, 2010).

Brau \& Woller, (2004), discussed field summary data from Kenya, Malawi, and Ghana and concluded that fundamental structural changes in socioeconomic conditions and a deeper understanding of informal sector behavior are needed for microfinance to prove effective. Microcredit and Microfinance schemes are often accompanied by social service programmes that can empower the poor. In addition to providing funds for microenterprises or financial assistance to cover essential needs, microcredit and microfinance schemes promote the exchange of knowledge and experience within a group, the establishment of credit history and financial experience and the acquisition of livelihood skills and health information (UN, 2010).

\section{Microfinance in Kenya}

According to the Association of Chartered Certified Accountants, ACCA (2011), Kenya's microfinance industry has been operating since the 1980s and became more prominent particularly when the Microfinance Act Laws of Kenya was established in 2006. They reiterate further that the Economist Intelligence Unit (EIU) rates Kenya as having the second best business environment for Microfinance Institutions (MFIs) in all of Africa, and one of the top ten in the world (EIU, 2010), and that Kenya has the second largest borrower base in the continent of Africa and it has the largest savings and credit cooperatives Societies (SACCO) movement (Johnston 2006; ACCA, 2011)

The Central Bank of Kenya (CBK) recognizes the role that financial inclusion plays in fighting poverty, and desires to promote the savings investment cycles that lead to economic development (Vizcarra, Ngahu \& Ramji, 2013). According to the FSD Kenya (2011), Fin Access survey 2009, the biggest growth in the financial services sector came from non-bank financial institutions, specifically with the growth of the M-pesa product over the last four years, and that the Savings and Credit Cooperative Societies (SACCO) and MFIs industries are the biggest contributors, given that Kenya has the largest SACCO market share in Africa. Table 2.1 reflects the "Big 4" SACCO countries in Africa. 
INTERNATIONAL JOURNAL OF ACADEMIC RESEARCH IN BUSINESS AND SOCIAL SCIENCES Vol. 10, No. 7, July, 2020, E-ISSN: 2222-6990 @ 2020 HRMARS

Table 2.1, Africa's largest SACCO markets

\begin{tabular}{|l|r|r|r|r|r|}
\hline Country & $\begin{array}{l}\text { No. of } \\
\text { Credit } \\
\text { Unions }\end{array}$ & Members & \multicolumn{1}{l|}{$\begin{array}{l}\text { Penetrati } \\
\text { on }\end{array}$} & Savings (USD) & \multicolumn{1}{l|}{ Loans (USD) } \\
\hline Ethiopia & 5,975 & 477,817 & $1.1 \%$ & $88,381,822.00$ & $12,846,339.00$ \\
\hline Kenya & 3,990 & $3,682,272$ & $17.1 \%$ & $2,269,620,502.00$ & $1,978,861,845.00$ \\
\hline Tanzania & 3,896 & 480,000 & $2.2 \%$ & $29,511,252.00$ & $24,251,349.00$ \\
\hline Uganda & 2,401 & 880,000 & $5.7 \%$ & $55,442,523.00$ & $47,812,818.00$ \\
\hline Total: Africa & $\mathbf{1 8 , 2 2 0}$ & $\mathbf{2 0 , 1 1 6 , 9 2 1}$ & $\mathbf{8 . 8 \%}$ & $\mathbf{4 , 3 8 7 , 5 6 3 , 9 7 1 . 0 0}$ & $\mathbf{3 , 7 4 8 , 7 3 8 , 3 9 9 . 0 0}$ \\
\hline
\end{tabular}

Source: WOCCU 2008 Statistical Report www.woccu.org

The Association of Microfinance Institutions of Kenya (AMFI) has 41 members which range from microfinance banks, wholesale MFI"s, retail MFI"s, development institutions and insurance companies representing the entire landscape of the Microfinance industry in Kenya. Their membership serves over 4 million clients with an outstanding loan portfolio of over $\$ 300$ million (Ahmed \& Karunditu, 2010).

\section{Microfinance in Economic Development}

Microfinance is vital to the development of entrepreneurship. The major contribution of microfinance institutions to the developing economy is its role in promoting entrepreneurship development in the nation (Osunde, 2012). Financial services play a critical role in the development of the country by providing intermediation between saving and investments (GOK, 2007). United Nations Capital Development Fund (UNCDF) (2003), reiterate that studies shows microfinance playing three key roles in development. 1) It helps very poor households meet basic needs and protects against risks, 2) it is associated with improvements in household economic welfare, and 3) it helps to empower women by supporting women's economic participation and so promotes gender equity.

As trusted business advisers, accountants working in or for ACCA (2011) believes that the microfinance industry is, on the whole, a force for good in Kenya and the wider world and can look forward to further growth as it continues to make inroads into its enormous potential market. They see the sector as a substantial employer of Kenya's finance professionals and will continue to pursue ever-closer partnerships with market participants and authorities. But they also recognize that microfinance is only one of the development tools at the nation's disposal and that its effectiveness must be measured against the ex-ante claims of practitioners, not the well-meaning desires of proponents at home or abroad.

\section{Conceptual Framework}

Makorere (2014), underscore the conceptual framework to be governed by microeconomic theory. Traditional microeconomic theory treats finance as a corporate factor of production. Irrespective of firm size and age, finance is normally required for three standard uses, that is for start-up capital in machinery and acquisition of buildings, financing working capital during start-up or while expanding and purchase of operating materials. The conceptual framework is therefore represented by Figure 2.1 
INTERNATIONAL JOURNAL OF ACADEMIC RESEARCH IN BUSINESS AND SOCIAL SCIENCES Vol. 10, No. 7, July, 2020, E-ISSN: 2222-6990 @ 2020 HRMARS

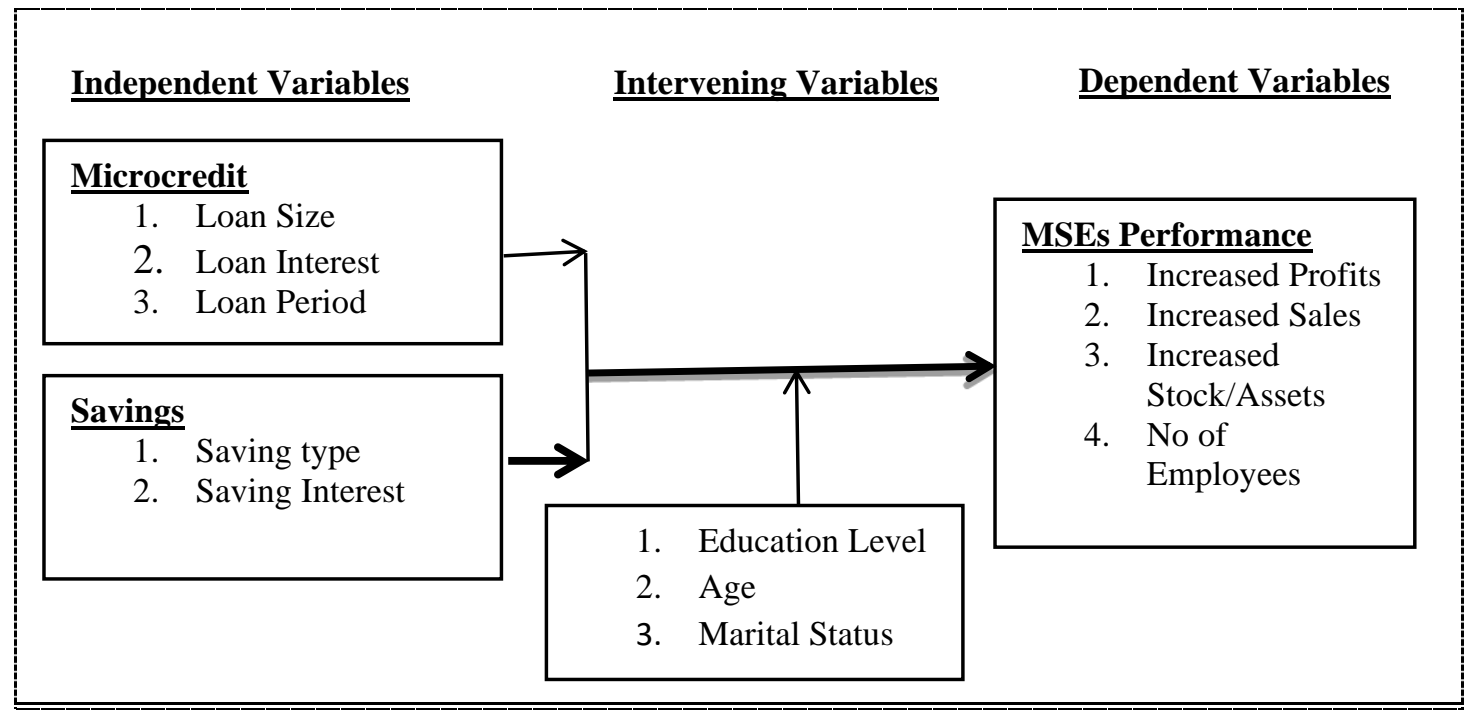

Source: Researcher

Figure 2.1; Study Conceptual Framework

\section{Gaps found from the Empirical Literature Review}

The role of microfinance in influencing the development of entrepreneurship has not been widely researched and even the information available is inconclusive as they look at the entrepreneur's welfare mostly and pay little attention to the growth and development of the enterprise (Morduch et al., 2002). The impact of microfinance on Micro and Small Enterprise survival and growth has not been empirically tested in the literature, especially in parts of Western Kenya. It is empirically proven that when you track the impact of micro financing on household or welfare of the entrepreneurs there are significant element of positive changes realized, but as for how this translates into the growth and development of his or her enterprise is of at most importance to be ascertained (EIB, 2008). This study therefore becomes significant in filling this observed gap by testing empirically the impact of the Microcredit and Savings Mobilization offered by Microfinance Institutions on MSEs growth and expansion capacity.

\section{Methodology}

ixed methods survey design was used to collect and analyze data. The combination of the methods allows for the integration of data collection and analysis techniques for both quantitative and qualitative methods in either parallel or sequential stages. Triangulation, complementarity, development initiation, expansion and enhance significant findings is facilitated through mixed research design (Salehi \& Golafshani, 2015).

\section{Target Population}

The study targeted 65,698 licensed Micro, Small and Medium Enterprises (MSMEs) in the three Counties of Kisumu, Siaya and Vihiga. The total numbers of MSMEs in the three Counties according to the Kenya National Bureau of Statistics MSMEs survey Report of 2016 are 531,698 which include the unlicensed MSMEs. Mugenda (2003) defines population as entire group of individuals, events or objects having common observable characteristic. The table 3.1 below shows the aggregation of the MSMEs per county based on their sizes, license status, as well as the total for the three Counties. 
INTERNATIONAL JOURNAL OF ACADEMIC RESEARCH IN BUSINESS AND SOCIAL SCIENCES Vol. 10, No. 7, July, 2020, E-ISSN: 2222-6990 @ 2020 HRMARS

Table 3.1; Distribution of licensed and Unlicensed MSMEs by County

\begin{tabular}{|c|c|c|c|c|c|c|}
\hline \multirow[b]{2}{*}{ County } & \multirow[b]{2}{*}{ Total } & \multicolumn{2}{|c|}{ Licensed } & \multicolumn{3}{|c|}{ Unlicensed } \\
\hline & & Micro & Small & Medium & & $\begin{array}{l}\text { Grand } \\
\text { Total }\end{array}$ \\
\hline Kisumu & 40,199 & 34,009 & 5,306 & 884 & 197,000 & 237,199 \\
\hline Siaya & 14,199 & 13,802 & 312 & 85 & 190,500 & 204,699 \\
\hline Vihiga & 11,300 & 10,848 & 441 & 11 & 78,500 & 89,800 \\
\hline Total & 65,698 & 58,659 & 6,059 & 980 & 466,000 & 531,698 \\
\hline
\end{tabular}

Source; KNBS, (2016)

\section{Sample Size and Sampling Technique}

The sample size was 398 calculated using Yamane (1967) model to determine the appropriate sample size.

$$
n=\frac{N}{1+N(e) 2}
$$

Where:

$n$ is the desired Sample size, $N$ is the Population size and, $e$ is the level of Precision

Therefore:

$$
n=\frac{65,698}{1+65,698(0.05)(0.05)} \quad n \text { is therefore } 398
$$

This was reinforced by stratified selection of licensed MSMSEs from Counties of Kisumu, Siaya and Vihiga as shown in table 3.2

Table 3.2; Distribution of Sample size to the Counties MSMEs

\begin{tabular}{lccc}
\hline County & Total & $\%$ & Sample \\
\hline Kisumu & 40,199 & 0.606 & 244 \\
Siaya & 14,199 & 0.606 & 86 \\
Vihiga & 11,300 & 0.606 & 68 \\
Total & 65,698 & 0.606 & 398 \\
\hline
\end{tabular}

Adapted from KNBS, (2016)

\section{Data Collection Instrument}

The study used a questionnaire to collect quantitative data and Secondary data was collected from review of relevant documents.

\section{Data Reliability Analysis}

Reliability is the extent to which a scale produces consistent results if repeated measurements are undertaken (Malhotra, 2010, as cited in Dubihlela, 2012,). Calculation of coefficient alpha (also known as Cronbach alpha) is done to assess the reliability of a multiple-item variable. Reliability analysis was 
INTERNATIONAL JOURNAL OF ACADEMIC RESEARCH IN BUSINESS AND SOCIAL SCIENCES

Vol. 10, No. 7, July, 2020, E-ISSN: 2222-6990 @ 2020 HRMARS

therefore done using Cronbach's Alpha as the measure. A reliability co-efficient of $\alpha \geq 0.7$ was considered adequate. Cronbach Alpha was established for every objective which formed a scale. The table, 3.3 shows the respective Cronbach alpha as per the study objective.

Table, 3.3, Reliability Statistics

\begin{tabular}{lll}
\hline Scale/Study objective & Cronbach's Alpha & $\begin{array}{l}\text { No } \\
\text { Items }\end{array}$ \\
\hline $\begin{array}{l}\text { Objective 1: Assess the effects of microcredit on } \\
\text { the growth and expansion of MSEs in Kenya }\end{array}$ & .905 & 5 \\
$\begin{array}{l}\text { Objective 2: Establish the effects of savings on } \\
\text { the performance of MSEs in Kenya }\end{array}$ & .743 & 4 \\
\hline
\end{tabular}

Source: Field Survey Data, 2020.

Table 3.3 shows that the two objective scales of measurement passed reliability test of cronbach alpha as all of them had $\alpha>$.7. Objective 1 , and 2 had ( $\alpha=0.905),(\alpha=0.743)$ respectively, signifying high internal consistency for the likert scales used.

\section{Data Analysis and Presentation}

Computer supported software SPSS was used to analyze quantitative data which was presented in descriptive and inferential statistics. Qualitative data was analyzed thematically and presented in prose. The multiple linear models used for quantitative analysis is provided below.

$\mathbf{Y}=\boldsymbol{\beta} \mathbf{0}+\boldsymbol{\beta} \mathbf{1 X} \mathbf{1}+\boldsymbol{\beta} \mathbf{2 X} \mathbf{2}+\boldsymbol{\varepsilon}, \mathbf{W h e r e :} \mathbf{Y}=$ SMEs Performance; $\mathbf{X} \mathbf{1}=$ Access to microcredit, $\mathbf{X} 2=$ Savings mobilization; $\boldsymbol{\varepsilon}=$ Error term;

While the $\boldsymbol{\beta} \mathbf{0}, \boldsymbol{\beta}_{1}$....B2 represent regression coefficients, and independent variables were represented by $\mathbf{X} \mathbf{1}, \mathbf{X} \mathbf{2}$ and $\boldsymbol{\varepsilon}$ provided for the random variation in $\mathbf{Y}$ that $\mathbf{X}$ variable was not able to explain.

\section{Findings and Discussions}

\section{Response Rate}

As planned all 398 respondents were reached, thus having a response rate of a $100 \%$, this was due to face to face interview method used indicating the responses collectively exceeded the threshold of representativeness.

\section{Demographic Information}

\section{Gender of Respondents}

211(53\%) respondents were male while 187 (46.9\%) were females. Since the MSEs respondents surveyed were Licensed and more formal, this conforms with the findings of Kenya National Bureau Statistics survey of MSMEs in 2016 which found more male in licensed MSEs than females and more females in unlicensed MSEs than Males (KNBS, 2016) and APEC, (2016) contend that women are more likely than men to operate in the informal sector - with $85.1 \%$ of women-owned MSEs being informal vis-à-vis $76.7 \%$ of men-owned MSEs being informal in the Asia-Pacific Economic Cooperation (APEC) region. 
INTERNATIONAL JOURNAL OF ACADEMIC RESEARCH IN BUSINESS AND SOCIAL SCIENCES Vol. 10, No. 7, July, 2020, E-ISSN: 2222-6990 @ 2020 HRMARS

\section{Education Level of Respondents}

As regards Education levels attained by respondents, $30(14.2 \%)$ of male and $28(15 \%)$ of female had Primary education, $79(37.4 \%)$ of male and 83 (44.4\%) of females had secondary education, 70 (33.2\%) of male and 57 (30.5\%) of females had technical training while 32 (15.2\%) of males and 19 (10.2\%) of females had University education. From the data it shows that majority of respondents had secondary education which is at $40.7 \%$, followed by technical college Education at $31.9 \%$, Primary and University education are at $14.6 \%$ and $12.8 \%$ respectively. Gachuhi, (2016), study findings indicate a strong positive relationship between social factors which includes levels of education and MSE growth. Leitao \& Franco (2011) found that, high levels of education of MSEs owners influence the performance of MSEs positively. Hisrich et al, (2008) reckon that, although formal education is not necessary for starting a new business, it's important in the upbringing of the entrepreneur and provide good background especially if it's related to the field of the venture. World Bank, (2016), survey of Kenya informal enterprises found out that, growth was seen in companies where owners had a secondary education (32 percent of firms) vs. owners who had no primary education (16.6 percent of firms).

\section{Age of Respondents}

Among the male entrepreneurs, $14(6.6 \%)$ are aged 30 years and below while $23(12.3 \%)$ of females are in the same age group.94 (44.5\%) of males are aged between 31 and 42 years, 98 (52.4\%) of females are in the same age group. $68(32.2 \%)$ of males are in the age group between 43 and 54 years, while $53(28.3 \%)$ of females are in the same age group. 27 (12.8\%) of males are between 55-66years, while $10(5.3 \%)$ of females are in the same age group. Only $8(3.8 \%)$ of males are 67 and above years while only $3(1.6 \%)$ of females are in the same age bracket. There is more concentration of ages between 31 years to 54 years, an indication of normal categorization of productive age. A study by Nabutola, (2015) confirms that there are more entrepreneurs in the middle Ages between 31 to 42 years; she argues that younger owner/manager has the necessary motivation, energy and commitment to work and is more inclined to take risks and more entrepreneurially active hence improved Performance of MSEs. Age was found to have significant effect on access to bank loan. Therefore, policy makers, banks, and other development partners should promote young owner/managers (Ogubazghi, \& Muturi, 2014). Age was also found to be a key determinant of entrepreneurial success (Wambua, \& Munyithya, 2015). Hisrich et al, (2008) agreed that most entrepreneurs initiate their entrepreneurial careers between the ages of 22 and 45 years. He contends that a career can be initiated before or after these ages, as long as the entrepreneur has the necessary experience and financial support.

\section{Marital Status of Respondents}

Among the male respondents, $22(10.4 \%)$ are single while 28 (13\%) of females are single as well. 172 $(81.5 \%)$ of male and $131(70.1 \%)$ of female are married. $10(4.7 \%)$ of male and $16(8.6 \%)$ of female are widowed. Lastly 7 (3.3\%) of male and $12(6.4 \%)$ of female are divorced. It shows that there are more married respondents at 76.1\%; The study findings are in line with those of Wambua\& Munyithya, (2015) where marital status was found to be a key determinant of entrepreneurial success. Mutoko \& Kapunda, (2017) found that as the number of married people's applications for loan increases, the rate at which the number of unmarried people receiving a loan for their businesses will reduce, showing the married people are more preferred. Byrne, Tounés, Giacomin \&Fattoum, 
INTERNATIONAL JOURNAL OF ACADEMIC RESEARCH IN BUSINESS AND SOCIAL SCIENCES

Vol. 10, No. 7, July, 2020, E-ISSN: 2222-6990 @ 2020 HRMARS

(2016) found to the contrary that single entrepreneurs have higher growth intentions than married or partnered entrepreneurs.

\section{Business performance based on Microcredit Services}

The study sought to know the extent to which the Performance of MSEs, on performance parameters used as a result of being exposed to Microcredit. The extent was measured on a Likert Scale of 1-5 where 5- Extremely, 4- Moderately, 3- Slightly, 2- Very Slightly, and 1- Not at all. The results of the study are as shown in Table 4.1.

Table 4.1, Business Performance Measurement

\begin{tabular}{llll}
\hline Growth and Expansion Indicators & N & Mean & Std. Deviation \\
Loan Affects Business Profits & 391 & 3.28 & .985 \\
Loan Affects Business Sales & 391 & 3.37 & .994 \\
Loan Affects Business Stock/Assets & 391 & 3.55 & 1.021 \\
Loan Affects No. of Employees & 391 & 2.15 & 1.243 \\
Total & $\mathbf{3 9 1}$ & $\mathbf{3 . 0 9}$ & $\mathbf{1 . 0 6 1}$ \\
\hline
\end{tabular}

Source: Field Survey, 2020.

In table 4.1, the respondents rated their business to be experiencing between slightly and moderate growth and expansion when they use microcredit for increase in stock or business assets $(M=3.55$, $S D=1.021)$. For growth and expansion on profits and Sales it show slight increase at $(M=3.28$, $\mathrm{SD}=.985)$ and $(\mathrm{M}=3.37, \mathrm{SD}=.994)$ respectively. It's only in growth and expansion of employees that increase is below average at $(M=2.15, S D=1.243)$. Overall rating of the Microcredit on performance of profit, Sales, Stock and employees is above average $(M=3.09, S D=1.061)$ thus it's a good indicator for MSEs growth and Expansion.

\section{Regression Analysis}

The regression analysis of the model determined the influence of the independent variables-Access to Microcredit and Savings Mobilization on the dependent variable MSEs Performance.

Table 4.2, Model Summary

\begin{tabular}{|l|l|l|l|l|}
\hline Model & $\mathrm{R}$ & R Square & $\begin{array}{l}\text { Adjusted } \mathrm{R} \\
\text { Square }\end{array}$ & $\begin{array}{l}\text { Std. Error of the } \\
\text { Estimate }\end{array}$ \\
\hline 1 & $.272^{\mathrm{a}}$ & .074 & .069 & .843 \\
\hline
\end{tabular}

a. Predictors: (Constant), Savings mobilization, Access to credit

Source: Research Data 2020

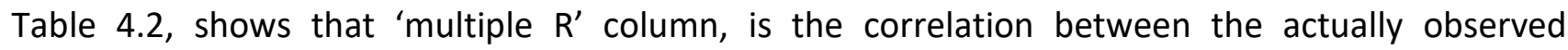
independent variables and the predicted dependent variable. ' $R$ square' is the square of $R$ and is also known as the 'coefficient of determination' (Ojo, 2009). In this study, R square is .074, which shows that $7.4 \%$ of the variations in MSEs Performance could be accounted for by the Microfinance Services. 
INTERNATIONAL JOURNAL OF ACADEMIC RESEARCH IN BUSINESS AND SOCIAL SCIENCES Vol. 10, No. 7, July, 2020, E-ISSN: 2222-6990 @ 2020 HRMARS

Table, 4.3, Coefficients ${ }^{\mathrm{a}}$

\begin{tabular}{|c|c|c|c|c|c|c|}
\hline \multirow{2}{*}{\multicolumn{2}{|c|}{ Model }} & \multicolumn{2}{|c|}{$\begin{array}{l}\text { Unstandardized } \\
\text { Coefficients }\end{array}$} & \multirow{2}{*}{$\begin{array}{l}\text { Standardized } \\
\text { Coefficients } \\
\text { Beta }\end{array}$} & \multirow[t]{2}{*}{$t$} & \multirow[t]{2}{*}{ Sig. } \\
\hline & & B & Std. Error & & & \\
\hline \multirow{3}{*}{1} & (Constant) & 2.727 & .165 & & 16.505 & .000 \\
\hline & Access to credit & -.136 & .040 & -.173 & -3.408 & .001 \\
\hline & Savings mobilization & .245 & .050 & .248 & 4.896 & .000 \\
\hline
\end{tabular}

a. Dependent Variable: SMEs performance

Source: Author's computation from study Sample Data 2020

Table 4.3, presents the regression coefficient with a constant ( $p$-value $=0.000)$ of 2.727. A constant of 2.727 indicates that without considering Access to credit and Savings Mobilization, other factors affect MSEs Performance. The results of Access to credit has $P$ value of $(P=001)$ at $(B=-.136)$, this means that Access to credit was significant $(p$-value $=0.001)$. The study concludes that a unit increase in Access to credit would lead to $13.6 \%$ negative change in MSEs Performance, while Savings Mobilization has a positive linear relationship with a coefficient of .245, and a $P$ value of $(P=.001)$, showing that Savings Mobilization is statistically significant. The study therefore concludes that Savings mobilization has an influence on the MSEs Performance, where a unit increase of Savings mobilization leads to $24.5 \%$ increase in MSEs Performance. Therefore from the coefficients Table: 4.3 , the general form of the linear regression model equation that was established is as follows;

$Y=2.727-0.136 X 1+0.245 X 2+\varepsilon$. Where $Y=M S E s$ Performance, $X \mathbf{1}=$ Access to microcredit, $\mathbf{X} \mathbf{2}=$ Savings Mobilization, $\boldsymbol{\varepsilon}=$ Random Variation.

Table, 4.4, ANOVA $^{\mathrm{a}}$

\begin{tabular}{|ll|l|l|l|l|l|}
\hline \multicolumn{2}{|l|}{ Model } & Sum of Squares & $\mathrm{df}$ & Mean Square & $\mathrm{F}$ & Sig. \\
\hline \multirow{3}{*}{1} & Regression & 21.293 & 2 & 10.647 & 14.966 & $.000^{\mathrm{b}}$ \\
& Residual & 267.475 & 376 & .711 & & \\
& Total & 288.768 & 378 & & & \\
\hline
\end{tabular}

a. Dependent Variable: SMEs performance

b. Predictors: (Constant), Savings mobilization, Access to credit

Source: Author's computation from study Sample Data 2020

Table, 4.4 shows that the relationship between Access to credit, Savings Mobilization and MSEs Performance are significant since $p$-value of 0.001 is less than 0.05 , for the model indicates that it is statistically significant in explaining the relationship between the independent and dependent variables. It was, therefore, concluded that Access to credit and Savings Mobilization had a significant combined influence on MSEs Performance in the Three selected Counties of Western Kenya which are Kisumu, Siaya and Vihiga. 
INTERNATIONAL JOURNAL OF ACADEMIC RESEARCH IN BUSINESS AND SOCIAL SCIENCES Vol. 10, No. 7, July, 2020, E-ISSN: 2222-6990 @ 2020 HRMARS

Table, 4.5, Correlations

\begin{tabular}{|l|l|l|l|l|}
\hline \multicolumn{2}{|c|}{} & $\begin{array}{l}\text { SMEs } \\
\text { performance }\end{array}$ & Access to credit & $\begin{array}{l}\text { Savings } \\
\text { mobilization }\end{array}$ \\
\hline \multirow{3}{*}{ SMEs performance } & Pearson Correlation & 1 & $-.126^{*}$ & $.212^{* *}$ \\
\cline { 2 - 5 } & Sig. (2-tailed) & & .013 & .000 \\
\cline { 2 - 5 } & $\mathrm{N}$ & 391 & 391 & 379 \\
\hline \multirow{3}{*}{ Access to credit } & Pearson Correlation & $-.126^{*}$ & 1 & $.208^{* *}$ \\
\cline { 2 - 5 } & Sig. (2-tailed) & .013 & 391 & .000 \\
\cline { 2 - 5 } & $\mathrm{N}$ & 391 & $.208^{* *}$ & 1 \\
\hline \multirow{3}{*}{ Savings mobilization } & Pearson Correlation & $.212^{* *}$ & .000 & \\
\cline { 2 - 6 } & Sig. (2-tailed) & .000 & 379 & 379 \\
\cline { 2 - 5 } & $\mathrm{N}$ & 379 & & \\
\hline
\end{tabular}

*. Correlation is significant at the 0.05 level (2-tailed).

**. Correlation is significant at the 0.01 level (2-tailed).

Source: Author's computation from study Sample Data 2020

As shown in table 4.5, the study found out that there was an inverse relationship between MSEs Performance and Access to credit. The correlation between MSEs Performance and Access to credit was found to be statistically significant ( $r s=-.126, n=391, p=.013$ ) two tail. There was a significant, positive association between MSEs Performance and Savings Mobilization. The correlation between MSEs Performance and Savings Mobilization was found to be statistically significant. ( $r s=.212, \mathrm{n}=$ $379, p=.001$ ) two tail. This clearly demonstrated that there existed a significant correlation between MSEs Performance and Access to credit and, Savings Mobilization.

\section{Summary of Research Findings, Conclusion and Recommendations}

This study mainly focused on the effects of Microfinancing on Performance of Entrepreneurship in Kenya, it looked at, MSEs access to credit and Savings Mobilization and whether they influence the growth and expansion of MSEs.

Objective one sought to assess the effects of microcredit on the growth and expansion of MSEs in Kenya. The findings indicated that access to microcredit played an important role in improving business profit; sales, assets and stock growth but seem to play a very minor role in increasing employment by the MSEs. This could be due to the fact that most MSEs are individually or family owned and managed and thus have less need for employing more workers.

Objective two sought to establish the effects of savings on the performance of MSEs in Kenya. The study established that savings mobilization contributes significantly to MSEs Performance. Most of the MSEs and especially rural based have less formal facilities to save except Microfinance institutions, therefore they are able to save as little as they earn periodically with the MFIs, many of which are within their reach. These savings are not only used for increasing working capital, but as well guard them against shocks, like sicknesses, other calamities, as well as family consumptions flactuations. Overally Microfincing services of Microfinance Institutions facilitate the growth and development of the MSEs in Kenya and especially in the Counties of Kisumu, Siaya and Vihiga. 


\section{Implications of the Study}

The research findings will give an impetus to MSEs owners and potential Micro-entrepreneurs to seek for financing from Microfinance Institutions and even MSEs sepecilized financial institutions, for their growth and expansion. This would enable more MSEs to survive longer in the market and thus contribute more to the development of the Kenyan economy. The findings can also encourage the MSEs to mobilize savings to not only guard them against economic shocks but as well calamities and family consumption fluctuations, the savings will also provide them with readily available cash for expanding their MSEs.

The study findings can also be used by the Microfinance Institutions as a basis to gauge the capacity of MSEs as their customers and therefore develop more MSEs friendly policies to expand on their outreach, this as well will boost the Kenyan economy as more MSEs will be in operation.

The study was anchored on Shane (2003) general theory of entrepreneurship and Yunus (1999) classic microfinance theory of change. The Shane (2003) looks at opportunity discovery and decision to exploit the opportunity, Shane also believed that for Entrepreneur to exploit the opportunity he/she must have certain capacity including financial capacity. Therefore the Theory is important to potential and practicing entrepreneurs to realize that they need to have capacities to exploit opportunities around them, and one of the capacities is the financial capacity. At the same time Yunus (1999) classic microfinance theory of change, emphasis on the potential development and long lasting change that come with Entrepreneurs access to microcredit facilities. In overall therefore Entrepreneurs requires an opportunity and a capacity to exploit the opportunity which to some extend can be derived from access to microcredit.

\section{Conclusion}

The study findings indicate that there is a significant relationship between the independent variables namely: access to microcredit, and savings mobilization to the overall MSEs performance. The access to microcredit and savings Mobilizations has facilitated the improvement of business profits, business assets including stocks, business sales and to some extent improvement in employment. Even though microfinance institutions operating environment is now regulated in Kenya, their operations needs to be supported for scale up, to sustain their support for the MSEs.

\section{Recommendations}

The study recommends establishment of Public Private Partnership and provide guarantee fund to the specialized financial institutions, to encourage them in funding MSEs.

Kenya Government to provide tax relief to Microfinance and other financial institutions targeting MSEs as an incentive.

\section{Suggestions for Further Research}

The study focused on the micro finance services on licensed MSEs in three counties of Kisumu, Siaya and Vihiga. The same study could be conducted in other counties. An in-depth study could also be conducted to find out how financing of the MSEs would enable MSEs increase employment, since this study did not find significant evidence to conclude that microfinancing MSEs leads to increase in employment. 
INTERNATIONAL JOURNAL OF ACADEMIC RESEARCH IN BUSINESS AND SOCIAL SCIENCES

Vol. 10, No. 7, July, 2020, E-ISSN: 2222-6990 @ 2020 HRMARS

\section{References}

ACCA. (2011). The future of microfinance in Kenya. ACCA's conference, 'Better Business Kenya $2011^{\prime}$, considered the prospects of the microfinance industry.

https://www.accaglobal.com/content/dam/acca/global/PDF-technical/small-business/polaf-bbk.pdf $>$ accessed $7^{\text {th }}$ July 2020.

AfDB, OECD, UNDP, and UNECA. (2011). African Economic Outlook 2011; Africa and its emerging partners.

Ahmed, R., and Karunditu, S. (2010). Kenya credit provider's association roadmap 2010 - 2015;

Financial Sector Deepening.

Andrianaivo, M., and Kpodar, K. (2011). ICT, financial inclusion, and growth: Evidence from African

Countries. IMF Working Paper, International Monetary Fund

APEC. (2016). Gender-related Constraints Faced by Women-owned SMEs; APEC Policy Support Unit. POLICY BRIEF No.15.

Ayyagari, M. T. B., and Demirgüç-Kunt, A. (2007). "Small and Medium Enterprises across the Globe", Small Business Economics 29, 415-434. Researchgate.

Banerjee, A., Duflo, E., Glennerster, R., and Kinnan, C. (2009).The miracle of microfinance? Evidence from a randomized evaluation. JEL codes: O16, G21, D21

Bateman, M. (2019). Impacts of the microcredit model: Does theory reflect actual practice? Researchgate: https://www.researchgate.net/publication/328419129

Berger, A. N., and Udell, G. F. (1998). The economics of small business finance: The roles of private equity and debt markets in the financial growth cycle, Journal of Banking and Finance 22 (6), 613-673.

Bouazza, A. B., Ardjouman, D., and Abada, O. (2015).Establishing the factors affecting the growth of small and medium-sized enterprises in Algeria; American International Journal of Social Science Vol. 4, No. 2.

Brau, J. C., and Woller, G. M. (2004). Microfinance: A comprehensive review of the existing literature, Journal of Entrepreneurial Finance, JEF, ISSN 1551-9570, Vol. 9, Iss. 1, pp. 1-27.

Byrne, J., and Humble. (2007).An introduction to mixed research method; Atlantic Research Center for Family Work Issues.

Byrne, J., Tounés, A., Giacomin, O., and Fattoum, S. (2016). For better or worse? Marital status, parental status and entrepreneurial growth intentions. Researchgate:

https://www.researchgate.net/publication/303814553

Cantillon, R. (1755). "Essay on the Nature of General Commerce", London, P. 48.

Cook, Tamara, and McKay, C. (2015). "How M-Shwari Works: The Story So Far." Forum 10. Washington, D.C.: CGAP and FSD Kenya. License: Creative Commons Attribution CC BY 3.0, http:// creativecommons.org/licenses/by/3.0.

Dubihlela, J. (2012).Barriers to and Determinants and Enablers of Market Orientation: Impact on Business Performance for Small and Medium Enterprises in South Africa Ewe know and what could be done differently? (PhD dissertation), North West University, South Africa.

Dunford, C. (2012). First Step in the Microfinance Theory of Change: Take a Loan or Save. Freedom from Hunger; http://microfinanceandworldhunger.org/2012/06/first-step-in-themicrofinance-theory-of-change-take-a-loan-or-save-do-they/ 
INTERNATIONAL JOURNAL OF ACADEMIC RESEARCH IN BUSINESS AND SOCIAL SCIENCES Vol. 10, No. 7, July, 2020, E-ISSN: 2222-6990 @ 2020 HRMARS

Egboro, F. (2015). Challenges of design, production and marketing department interface and customer satisfaction, African Journal of Business Management, Vol 9(14), pp.562-568, 28 July, 2015 Article Number: 70DEC5854552 ISSN 1993-8233 DOI: 10.5897/AJBM2014.7648

EIU. (2010).Global Microscope on the Microfinance Business Environment 2010. An index and study by the Economist Intelligence Unit.

https://publications.iadb.org/publications/english/document/Global-Microscope-on-theMicrofinance-Business-Environment-2010-An-Index-and-Study-by-the-EconomistIntelligence-Unit.pdf

European Investment Bank. (2008). A review of the economic and social impact of microfinance with analysis of options for the Mediterranean Region Final Report - April 2008 FacilityforEuro-M editeraneanInvestmentandPartnership.

FSD Kenya. (2011). Financial inclusion in Kenya Survey results and analysis from Fin Access 2009. ISBN Number: 978-9966-019-00-4

Gachuhi, S. M. (2016). An Evaluation of Socio-Economic Factors Influencing the Growth of Small and Medium Enterprises in Kenya: a Case Study of Nairobi County. United States International University Africa

Gibrat, R. (1931). Les inégalités économiques: applications: aux inégalitês des richesses, à la concentration des entreprises, aux population's des villes, aux statistiques des familles, etc: d'une loi nouvelle: la loi de l'effet proportionnel. Librairie du Recueil Sirey.

GOK. (Government of Kenya), (2003).Economic Recovery Strategy for Wealth and Employment Creation 2003-2007. Nairobi: Ministry of Planning and National Development, Government Printer.

GOK. (1986). "Economic management for renewed growth". Sessional Paper No. 1 of 1986. Nairobi: Government Printer.

GOK. (1989). "A strategy for small enterprise development in Kenya: towards the Years 2000". Nairobi: Government Printer.

GOK. (2005) Sessional Paper No 2 of 2005 on Development of Micro and Small Enterprises for Wealth and Employment Creation for Poverty Reduction. Nairobi: Government Printer.

GOK. (2008) First Medium Term Plan, 2008 - 2012 Vision 2030. Government Printer, Nairobi Kenya.

GOK. (2012): Sustainable Development in Kenya: Stocktaking in the run up to Rio+20 Nairobi Kenya, 2012. Government Printer, Nairobi Kenya.

Haider, S. H., Asad, M., Fatima, M., and Atiq, H. (2017). Mediating role of opportunity recognition between credit, savings and performance of micro and small enterprises in Pakistan; Journal of Advanced Research in Business and Management Studies Journal homepage: www.akademiabaru.com/arbms.html

Hisrich, R. D., Peters, M. P., and Shepherd, D. A. (2008). Entrepreneurship African Edition, McGrawHill Education Publisher. https://www.researchgate.net/publication/303814553

ILO. (1972). "Employment, incomes and equity: a strategy of increasing productive employment in Kenya". Geneva: International Labour Organization. Information acquisition.

ILO. (2009).The informal economy in Africa: Promoting transition to formality: Challenges and strategies; International Labour Office, Employment and Social Protection Sector. - Geneva: ILO.

Kenya National Bureau of Statistics. (2016).Micro, Small and Medium establishment (MSME) Survey, Basic Report. Government Printers, Nairobi Kenya. 
INTERNATIONAL JOURNAL OF ACADEMIC RESEARCH IN BUSINESS AND SOCIAL SCIENCES

Vol. 10, No. 7, July, 2020, E-ISSN: 2222-6990 @ 2020 HRMARS

Khandker, S. R., \& Zaman, H. (2011).The impact of microfinance. The Daily Star. Retrieved from http://archive.thedailystar.net/newDesign/news-details.php?nid=1774 57.

Klein, P. G. (2008).Opportunity Discovery, Entrepreneurial Action, and Economic Organization Division of Applied Social Sciences and McQuinn Center for Entrepreneurial Leadership Strategic Entrepreneurship Journal.

KNBS (Kenya National Bureau of Statistics). (2003).Kenya National Economic Survey 2003, Ministry of Planning and National Development. Government Printer, Nairobi Kenya.

KNBS. (2012).Kenya National Bureau of Statistics, Economic Survey 2012. Government Printer, Nairobi Kenya.

KNBS. (2015). Kenya National Bureau of Statistics, Economic Survey 2015. Government Printer, Nairobi Kenya.

Koech, B. C. (2011). A Survey of the Financial Constraints Hindering Growth of SME"s In Kenya: The Case of Kamukunji District in Nairobi County. Unpublished MBA project University of Nairobi, 1-66.

Latha, K. L., Madhavaiah, C., and Murthya, B. E. V. V. N. (2008). Small Scale Entrepreneurship in India. Serbian Journal of Management 3 (2) (2008) 171 - 187.

Leitao, J., and Franco, M. (2011). Individual entrepreneurship capacity and small and medium enterprises (SME) performance: A human and organizational capital approach; African Journal of Business Management Vol. 5(15), pp. 6350-6365, 4 Available online at http://www.academicjournals.org/AJBM ISSN 1993-8233 C2011 Academic Journals.

Madara, M. W. O. (2005). The Implications of Microfinance on the provision of Sustainable Support to Orphans: a Case Study of East and South East Alego Siaya District. Kenyatta University Library, Kenya.

Makorere, R. (2014). The Role of Microfinance in Promoting Small and Medium Enterprises (SMEs) in Tanzania: Empirical Evidences from SMEs holder who have received Microcredit from Financial Institutions in Morogoro, Tanzania. Global Business and Economics Research Journal, 3(4): 1-19.

McFarlane, J. (2016). "Chapter 2 Economic Theories of Entrepreneurship" In: Arshed, N. \& Danson, M. (ed) . Oxford: Good fellow Publishers http://dx.doi.org/10.23912/978-1-910158-75-32880

Morduch, J., and Haley, B. (2002).Analysis of the Effects of Microfinance on Poverty Reduction. The NYU Wagner Working Paper Series No. 1014.

Micro and Small Enterprises Act Laws of Kenya, 2012

Mugenda, O., and Mugenda, A. G. (2003). Research Methods: Qualitative and Quantitative Approaches. Nairobi.Acts Press.

Muiruri, P. M. (2014).The role of Microfinance Institutions to the growth of Micro and Small Enterprises (MSE) in Thika, Kenya. (Empirical Review of Non-Financial Factors).International Journal of Academic Research in Accounting, Finance and Management Sciences Vol. 4, No.4, October 2014, pp. 249-262 E-ISSN: 2225-

Mukuria, N. H. (2014). The Effect of Banking Services on the Profitability of the top 100 Small and Medium Enterprises in Kenya. University of Nairobi Library

Mutoko, W., and Kapunda, S. M. (2017).Factors influencing small, medium and micro-sized enterprises" borrowing from banks: The case of the Botswana manufacturing sector. Acta 
INTERNATIONAL JOURNAL OF ACADEMIC RESEARCH IN BUSINESS AND SOCIAL SCIENCES

Vol. 10, No. 7, July, 2020, E-ISSN: 2222-6990 @ 2020 HRMARS

Commercii - Independent Research Journal in the Management Sciences ISSN: (Online) 16841999, (Print) 2413-1903

Nabutola, J. (2015). Factors influencing performance of SMEs in Central Business District Bungoma County, Kenya" University of Nairobi Library, Kenya.

Nair, A., Trendowski, J., \& Judge, B. (2008).The Theory of the Growth of the Firm, by Edith T. Penrose. Oxford: Blackwell, 1959 [book review]. Academy of Management Review, 33(4), 1026-1028.

Ogubazghi, S. K., \& Muturi, W. (2014). The Effect of Age and Educational Level of Owner/Managers on SMMEs" Access to Bank Loan in Eritrea: Evidence from Asmara City. American Journal of Industrial and Business Management, 2014, 4, 632-643

Ojo, O. (2009). Impact of microfinance on the entrepreneurial development: a case of Nigeria. The International Conference on Administration and Business.

Ong'olo, D., and Awino, S. (2013). Small and Medium Enterprises and Devolved Government System: an Assessment of the Regulatory and Institutional Challenges Affecting the SMEs Development in Kenya. Investment climate and business environment research fund. Trust Africa.

Oppong, T. (2015).Failed Startup Lessons.50 Startup Founders Reveal Why Their Startups Failed https://alltopstartups.com/wp-content/uploads/2015/05/Failedstartups_ebook.pdf

Osunde, C. (2012).Microfinance and Entrepreneurial Development in Nigeria; Jorind 10 (3), December, 2012. ISSN 1596 - 8308.www.transcampus.org./journals.Pakistan, Journal of Advanced Research in Business and Management Studies 7, Issue 2 (2017) 91-99

Penrose, E. (1995). The theory of the growth of the firm. Oxford: Oxford University Press.

Pietro, C., Chando, V. M., and Sofiane, S. (2012). Bank Financing to Small and Medium Enterprises In East Africa: Findings of A Survey in Kenya, Tanzania, Uganda and Zambia, Working Paper Series $N^{\circ} 146$, African Development Bank, Tunis, Tunisia.

Saleemi, N. A. (2011). Entrepreneurship Simplified, East African Edition. Saleemi Publications Itd.

Salehi, K., \&Golafshani, N. (2015). Using mixed methods in research studies: An opportunity with its challenges, International Journal of Multiple Research Approaches (2010) 4: 186-191.

Sarasvathy, S. (2014).The Downside of Entrepreneurial Opportunities. Dans management 2014/4 Vol. 17 https://www.cairn.info/revue-management-2014-4-page-305.htm

Shahini, B. (2016). Financial Constraints of Small and Medium Enterprises: Case of Albania, Journal of Social and Economic Statistics Vol. 5, No. 1, Summer Published by JSES.

Shane, S. (2003). A General Theory of Entrepreneurship: The Individual-Opportunity Nexus. Cheltenham, UK and Northampton, MA: Elgar.

Shepard, E. (2015).Situating micro-Finance on a theoretical spectrum: The case of Bolivia. Atlantic International Studies Organization.

Shravanvel, P. (1987). Development: Principles, Policies and Programmes, Ess-Pee- Kay Publishing House, Madras, p.21, 25.

Smallbone, D., North, D. J., and Leigh, R. (1993) The growth and survival of mature manufacturing SMEs in the 1980s: an urban-rural comparison. In: Curran, J. and Storey, D., (Eds.) Small Firms in Urban and Rural Locations, pp. 79-131. London: Routledge]

UN Report: (2010). Role of microcredit and microfinance in the eradication of poverty. United Nations Digital Library. 
INTERNATIONAL JOURNAL OF ACADEMIC RESEARCH IN BUSINESS AND SOCIAL SCIENCES

Vol. 10, No. 7, July, 2020, E-ISSN: 2222-6990 @ 2020 HRMARS

UNCDF. (2003).Microfinance Programme Impact Assessment 2003United Nations Capital

Development Fund Based on Case Studies in Haiti, Kenya, Malawi and Nigeria Final Report.

Enterprising Solutions Global Consulting, LLC. New York.

United Nations Industrial Development Organization (UNIDO), (2012). Annual report 2012.

United Nations. (2013).Microfinance in Africa, Overview and Suggestions for Action by Stakeholders. UN office of special adviser on Africa

Vizcarra, V., Ngahu, J. I., and Ramji, M. (2013). Mobile Financial Services in Microfinance Institutions: Musoni in Kenya, International Finance Corporation.

Wambua, P. P., and Munyithya, H. M. (2015). The Gender Factor Influence on Entrepreneurial Success in Kitui County, Kenya International Journal of Education and Research Vol. 3 No. 7 July 2015

White, S. (2018).Creating better business environments for micro and small enterprises", Technical Report, Donor Committee for Enterprise Development, Cambridge, UK.

World Bank. (2013). Kenya Enterprise Survey (http:www.enterprisesurveys.org)

World Bank. (2014). Private Equity and Venture Capital in SMEs in Developing Countries, The Role for Technical Assistance, Capital Markets Practice Non-Bank Financial Institutions Unit. The World Bank Washington DC.

World Bank. (2014).Kenya: A Sleeping Lion or Speedy Lioness? Country Economic Memorandum. Washington, DC: World Bank. Washington, DC.

World Bank. (2016).Informal Enterprises in Kenya. The World Bank. Washington, DC.

World Bank. (2019). Doing Business 2019, Training for reform, World Bank Publications.

Yamane, T. (1967).Statistics, an Introductory Analysis, 2nd Ed., New York: Harper and Row

Yunus, M. (1999).Banker to the Poor Micro-Lending and the Battle against World Poverty, Published by Public Affairs, a member of Perseus Books LLC288 pages. 